\title{
Ocena stężenia wybranych hormonów w surowicy oraz ocena morfologiczna, histochemiczna i immunohistochemiczna gruczołu krokowego z tagodnym rozrostem i ze wspótistniejącym zespołem metabolicznym*
}

\author{
The assessment of serum levels of selected hormones and morphological, histochemical \\ and immunohistochemical evaluation of the prostate gland in men with benign prostatic \\ hyperplasia and with coexisting metabolic syndrome
}

\author{
Aleksandra Ryt $\bowtie$ \\ Pomorski Uniwersytet Medyczny w Szczecinie, Katedra i Zakład Histologii i Biologii Rozwoju, ul. Żołnierska 48, 71-210 Szczecin \\ $\triangle$ ryl.ola@gmail.com
}

\begin{abstract}
Introduction: Benign prostatic hyperplasia (BPH) is one of the most common diseases occurring in aging men. The relationship between BPH and metabolic syndrome (MetS) has been poorly elucidated. Evidence was also provided for the relationship between disorders diagnosed in the course of MetS, the volume of the prostate. Metabolic syndrome may play a part in BPH progression.

The aim of this study was to assess the influence of the levels of selected hormones, and to make a morphological, histochemical, and immunohistochemical evaluation of the prostate in men with BPH and coexisting MetS.

Materials and methods: The study involved 151 men with diagnosed and surgically treated BPH. The control group consisted of 142 men without BPH. The men in the study and control groups were divided into subgroups: without MetS diagnosis and with MetS diagnosis. In both groups, anthropometric parameters were measured, and metabolic parameters and the levels of selected hormones and proteins - total testosterone, free testosterone, estradiol, insulin, dehydroepiandrosterone sulfate, luteinizing hormone, sex hormone binding protein and insulin-like growth factor-1 - in serum were determined. An immunohistochemical reaction was performed on the sections to identify an
\end{abstract}

androgen receptor (AR) and an oestrogen receptor $\alpha(E R \alpha)$, as well as a proliferating cell nuclear antigen (PCNA). Additionally, a histochemical reaction for apoptosis was performed using the TUNEL method. The preparations were scanned and subjected to computer image analysis.

Results and conclusions: Our study showed that a disturbed lipid profile in serum and a diagnosis of MetS were factors raising the risk of BPH. Changes in the levels of proteins, as well as metabolic and hormonal parameters, had no effects on the severity of clinical symptoms accompanying benign prostatic hyperplasia. Metabolic syndrome in BPH patients had no influence on the localization and expression of AR and ER $\alpha$ in the prostate cells. Nevertheless, metabolic disorders diagnosed in $\mathrm{BPH}$ patients may have an impact on the change in the balance between the number of AR(+) and $\operatorname{ER} \alpha(+)$ cells and hormone metabolism parameters. Metabolic syndrome in BPH patients had no influence on the number of TUNEL(+) and PCNA(+) cells in the prostate gland. An important factor decreasing the number of TUNEL(+) cells and increasing the number of PCNA(+) cells in BPH patients was central obesity.

Keywords: benign prostatic hyperplasia; metabolic syndrome; hormones.

\begin{abstract}
ABSTRAKT
Wstęp: Łagodny rozrost gruczołu krokowego (BPH) jest jedną z najczęstszych chorób występujących u mężczyzn w przebiegu procesu starzenia się. Udowodniono istnienie związku między zaburzeniami diagnozowanymi w przebiegu zespołu metabolicznego (MetS) a objętością stercza. Zespół metaboliczny może być jednym z czynników progresji BPH.

Celem badań była ocena wpływu stężeń wybranych hormonów oraz ocena morfologiczna, histochemiczna i immunohistochemiczna prostaty mężczyzn z BPH i współistniejącym MetS.

Materiały i metody: Badania przeprowadzono u 151 mężczyzn ze zdiagnozowanym i leczonym operacyjnie BPH. Grupę kontrolną
\end{abstract}

stanowiło 142 mężczyzn bez BPH. Mężczyzn z grupy badanej i kontrolnej podzielono na podgrupy bez zdiagnozowanego MetS oraz ze zdiagnozowanym MetS. W obu grupach oznaczono parametry antropometryczne, a w surowicy oznaczono parametry metaboliczne i stężenie wybranych hormonów: testosteronu całkowitego i testosteronu wolnego, estradiolu, insuliny, siarczanu dehydroepiandrosteronu, hormonu luteinizującego oraz białka wiążącego hormony płciowe i insulinopodobnego czynnika wzrostu 1. Na skrawkach wykonano reakcję immunohistochemiczną na identyfikację receptora androgenowego (AR) i estrogenowego $\alpha(E R \alpha)$ oraz jądrowego antygenu proliferacyjnego (PCNA). Wykonano również reakcję histochemiczną na identyfikację

*Zwięzła wersja rozprawy doktorskiej przyjętej przez Radę Wydziału Nauk o Zdrowiu Pomorskiego Uniwersytetu Medycznego w Szczecinie. Promotor: prof. dr hab. n. med. Maria Laszczyńska. Oryginał obejmuje: 137 stron, 33 tabele, 13 rycin i 234 pozycje piśmiennictwa. 
apoptozy metodą TUNEL. Przygotowane preparaty zostały zeskanowane i poddane komputerowej analizie obrazu. Wyniki i wnioski: Wykazano, że zaburzenie profilu lipidowego w surowicy oraz zespół metaboliczny były czynnikami zwiększającymi ryzyko wystąpienia BPH. Zmiany stężenia parametrów metabolicznych, hormonalnych i białek nie miały wpływu na stopnień nasilenia objawów klinicznych towarzyszących BPH. Zespół metaboliczny zdiagnozowany u pacjentów z BPH nie miał wpływu na lokalizację i ekspresję AR i ER $\alpha$ w komórkach prostaty. Zaburzenia metaboliczne diagnozowane w przebiegu
BPH mogą mieć jednak wpływ na zmianę równowagi między liczbą komórek AR(+) i $\mathrm{ER} \alpha(+)$ a parametrami gospodarki hormonalnej. Zespół metaboliczny zdiagnozowany u pacjentów z BPH nie miał wpływu na liczbę komórek TUNEL(+) i PCNA(+) $\mathrm{w}$ gruczole krokowym. Istotnym czynnikiem powodującym zmniejszenie liczby komórek TUNEL(+) oraz zwiększenie liczby komórek PCNA(+) u pacjentów z BPH było występowanie otyłości centralnej.

Słowa klucze: łagodny rozrost prostaty; zespół metaboliczny; hormony.

\section{WSTEP}

Łagodny rozrost gruczołu krokowego (benign prostatic hyperplasia - BPH) jest jedną z najczęstszych niezłośliwych chorób pojawiających się z wiekiem u mężczyzn. Choroba ta może być związana z postępującymi dokuczliwymi objawami ze strony dolnych dróg moczowych (lower urinary tract symptoms LUTS), które w znaczący sposób pogarszają jakość życia pacjentów. Pomimo wielu badań, zarówno klinicznych, jak i doświadczalnych, etiologia BPH nie została jeszcze do końca poznana [1].

Proces powstawania choroby ma wieloczynnikowe i skomplikowane podłoże. Obecnie znanych jest kilka czynników etiologicznych, z których ważną rolę odgrywają zaburzenia hormonalne [2, 3]. Androgeny są niezbędne do zachowania prawidłowej morfologii i funkcji gruczołu korkowego [3, 4].

Nieznaczny spadek stężenia testosteronu we krwi mężczyzn jest stanem fizjologicznym związanym ze starzeniem się organizmu. Jednak spadek stężenia testosteronu występujący w przebiegu rozrostu prostaty ze współistniejącymi zaburzeniami metabolicznymi jest kwestią sporną. Niezaprzeczalnie testosteron oraz produkt jego enzymatycznej przemiany dihydrotestosteron biorą udział we wzroście i proliferacji komórek stercza [5, 6]. Świadczy o tym m.in. fakt, że BPH nie występuje u mężczyzn poddanych wczesnej kastracji [7]. Apoptoza i proliferacja komórek prostaty jest związana zarówno z fizjologicznym wzrostem, jak i patologicznym rozrostem prostaty. Zaburzenia równowagi między proliferacją a apoptozą komórek mogą prowadzić do stałego wzrostu komórek nabłonka i zrębu, co jest jedną z przyczyn rozwoju BPH $[8,9]$.

Kluczowym czynnikiem łączącym zaburzenia metaboliczne i BPH jest hiperinsulinemia. Mechanizm tej zależności związany jest z wpływem hiperinsulinemii na aktywność współczulnego układu nerwowego, którego pobudzenie może przyczyniać się do zwiększania napięcia mięśni prostaty. Początkowo taki stan może być efektem progresji objawów ze strony LUTS, a w konsekwencji może prowadzić do powstawania patologicznego rozrostu gruczołu krokowego [10].

Pozostałe czynniki diagnostyczne zespołu metabolicznego (metabolic syndrome - MetS), czyli obniżone stężenie lipoproteiny o wysokiej gęstości (high density lipoprotein HDL) oraz podwyższone stężenie triglicerydów (triglycerides - TG), są również powiązane z BPH poprzez szlaki związane $\mathrm{z}$ powstawaniem stanu zapalnego $\mathrm{w}$ tym gruczole. Powstawanie ognisk zapalnych ma związek z wydzielaniem interleukiny 8 w odpowiedzi na oksydację lipoproteiny o niskiej gęstości (low density lipoprotein - LDL), ale także ze zwiększającym się stężeniem insuliny [11]. Istnienie tych zależności może sugerować, że współwystępowanie MetS z BPH i z LUTS może być celem terapii celowanej w leczeniu rozrostu prostaty.

Celem przeprowadzonych badań była ocena wpływu stężeń wybranych hormonów oraz ocena morfologiczna, histochemiczna (ocena apoptozy komórek) oraz immunohistochemiczna (ocena jądrowego białka proliferacyjnego, receptora androgenowego i estrogenowego $\alpha$ ) prostaty mężczyzn z BPH i współistniejącym MetS.

\section{MATERIAtY I METODY}

\section{Materiat - grupa badana}

W badaniu udział wzięło 151 pacjentów z BPH w wieku 52-89 lat - średnia $(\overline{\mathrm{X}}) \pm$ odchylenie standardowe (SD), zakwalifikowanych do planowanego zabiegu przezcewkowej resekcji gruczołu krokowego w Klinice Urologii i Onkologii Urologicznej w Samodzielnym Publicznym Szpitalu Klinicznym nr 2 Pomorskiego Uniwersytetu Medycznego w Szczecinie (PUM). Pacjenci zostali poproszeni o wypełnienie ankiet: standaryzowanego kwestionariusza niedomogi androgennej starzejących się mężczyzn autorstwa J.E. Morleya, standaryzowanej ankiety określającej skalę punktów dotyczących objawów towarzyszących chorobom gruczołu krokowego oraz metryczki.

Mężczyzn grupy badanej (B) podzielono na 2 podgrupy bez zdiagnozowanego MetS (B1) oraz ze zdiagnozowanym MetS (B2). W badaniu wykorzystano kryteria diagnostyczne MetS opracowane przez Międzynarodową Federację Diabetologiczną z 2005 r. Jako kryterium diagnostyczne przyjęto: otyłość brzuszną (obwód talii $\geq 94 \mathrm{~cm}$ ) i dodatkowo współistnienie co najmniej dwóch parametrów wykazujących odchylenie od normy: stężenia TG $\geq 150 \mathrm{mg} / \mathrm{dL}$ lub leczenia dyslipidemii, stężenia HDL $\leq 40 \mathrm{mg} / \mathrm{dL}$ lub leczenia dyslipidemii, ciśnienia tętniczego $\geq 130 / 85 \mathrm{mmHg}$ lub leczenia nadciśnienia tętniczego, glikemii na czczo $\geq 100 \mathrm{mg} / \mathrm{dL}$ lub leczenia cukrzycy typu 2 [12].

Na przeprowadzenie badań uzyskano zgodę Komisji Bioetycznej PUM nr: KB-0012/132/12.

\section{Materiat - grupa kontrolna}

Grupa kontrolna obejmowała 142 pacjentów w wieku 53-80 lat $(66,09 \pm 6,21)$ rekrutowanych z placówek podstawowej opieki 
zdrowotnej. Pacjenci nie zgłaszali problemów ze strony LUTS, nie mieli zdiagnozowanego BPH i nie pozostawali pod opieką poradni urologicznych. Mężczyzn z grupy kontrolnej (K) również podzielono na 2 podgrupy - bez zdiagnozowanego MetS (K1) oraz ze zdiagnozowanym MetS (K2).

\section{Metody}

U pacjentów z grupy B i K obliczono wskaźnik masy ciała (body mass index - BMI) wg wzoru: BMI = masa ciała $(\mathrm{kg}) /$ wzrost $^{2}(\mathrm{~m})$ [13]. U pacjentów, którzy nie chorowali na cukrzycę, obliczono współczynnik insulinooporności: HOMA-IR = stężenie glukozy na czczo $(\mathrm{mmol} / \mathrm{L}) \times$ stężenie insuliny na czczo $(\mu \mathrm{U} / \mathrm{mL}) / 22,5[14]$.

\section{Badania stężeń hormonów, białek i parametrów biochemicznych w surowicy}

Krew do badań biochemicznych i hormonalnych od mężczyzn z grupy B i K pobierano na czczo z żyły łokciowej. Krew była pobierana do probówek z aktywatorem krzepnięcia i separatorem żelowym (typu Vacoutainer) w ilości $9 \mathrm{~mL}$, a następnie odwirowywana. Surowicę przechowywano w temperaturze $-70^{\circ} \mathrm{C}$.

U wszystkich pacjentów biorących udział u badaniu wykonano pomiar obwodu brzucha oraz ciśnienia tętniczego krwi. W surowicy oznaczono metodą spektrofotometryczną, z wykorzystaniem gotowych zestawów odczynników (Biolabo, Aqua-Med, Łódź), parametry metaboliczne: stężenie glukozy na czczo (fasting plasma glucose - FPG) - u pacjentów bez cukrzycy, stężenie cholesterolu całkowitego (total cholesterol - CT), stężenie HDL, stężenie LDL i TG.

Metodą ELISA, za pomocą gotowych zestawów odczynników (DRG Medtec, Warszawa), oznaczono: stężenie testosteronu całkowitego (total testosterone - TT), testosteronu wolnego (free testosterone - TF), estradiolu (estradiol - E2), hormonu luteinizującego (luteinizing hormone - LH), insuliny - u pacjentów bez cukrzycy, globuliny wiążącej hormony płciowe (sex hormone binding globulin - SHBG), siarczanu dehydroepiandrosteronu (dehydroepiandrosterone sulfate - DHEAS) oraz insulinopodobnego czynnika wzrostu-1 (insulin-like growth factor-1 - IGF-1).

\section{Badania morfologiczne prostaty ludzkiej}

Fragmenty rozrostu prostaty, pobrane podczas zabiegu przezcewkowej resekcji gruczołu krokowego, utrwalano w zbuforowanej formalinie (4\%). Następnie płukano je w wodzie bieżącej i poddawano procedurze utrwalania w szeregu alkoholi o rosnących stężeniach. Bloczki parafinowe z zatopionymi fragmentami rozrostu prostaty były krojone na skrawki o grubości $3 \mu \mathrm{m}$ na mikrotomie. Skrawki zostały umieszczenie na szkiełkach podstawowych oraz szkiełkach podstawowych pokrytych polilizyną. Skrawki prostat mężczyzn barwiono metodą HE (hematoksylina-eozyna) w celu oceny ich budowy morfologicznej w mikroskopie świetlnym.

\section{Badania immunohistochemiczne}

W celu oznaczenia lokalizacji i ekspresji receptora androgenowego $(A R, n=60)$, receptora estrogenowego $\alpha(E R \alpha, n=61)$ oraz jądrowego antygenu proliferacyjnego (PCNA, $\mathrm{n}=64$ ) $\mathrm{w}$ prostacie mężczyzn z BPH skrawki badanych prostat odparafinowano i dokonano hydratacji w szeregu alkoholi o zmniejszającym się stężeniu. Następnie preparaty prostat gotowano w łaźni wodnej w temperaturze $96^{\circ} \mathrm{C}$ przez $30 \mathrm{~min}$ w buforze o $\mathrm{pH}$ 9,0. Aktywność endogennej peroksydazy blokowano za pomocą Peroxidase Bloking Solution (Dako, Dania), 10 min w komorze wilgotnej w temperaturze pokojowej. Skrawki inkubowano przez 30 min w komorze wilgotnej z pierwszorzędowymi monoklonalnymi przeciwciałami: przeciwko ludzkiemu receptorowi androgenowemu, stężenie 1: 50 (Dako, Dania), przeciwko HER $\alpha$, stężenie $1: 50$ (Dako, Dania), immunoglobulinami przeciwko PCNA, stężenie 1: 200 (Dako, Dania). W następnej kolejności skrawki inkubowano z kompleksem zawierającym drugorzędowe przeciwciało sprzężone z peroksydazą chrzanową

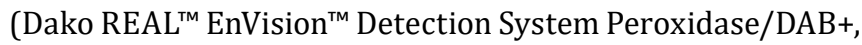
Rabbit/Mouse; Dako, Dania). Do wizualizacji reakcji immunohistochemicznej stosowano odczynnik DAB (Dako, Dania). Barwienie kontrastujące wykonano hematoksyliną Mayera. Skrawki poddano dehydratacji i zamknięto je w histokicie. Preparaty oceniano w mikroskopie świetlnym (BX 41, Olympus Optical Co., Tokyo, Japan).

\section{Badania histochemiczne}

W celu oznaczenia komórek w apoptozie w prostacie mężczyzn z BPH (n = 60) skrawki rozrostu prostaty odparafinowano i dokonano hydratacji. W celu odsłonięcia determinant antygenowych trawiono je proteinazą K (Dako, Dania). Aktywność endogennej peroksydazy blokowano przy użyciu Peroxidase Blocking Solution przez 10 min. Następnie skrawki inkubowano z terminalną transferazą dezoksynukleotydylową przez 60 min w komorze wilgotnej w $37^{\circ} \mathrm{C}$. Skrawki inkubowano z przeciwciałami przeciwko digoksygeninie przez 30 min w komorze wilgotnej w temperaturze pokojowej. W celu wizualizacji reakcji użyto DAB. Skrawki kontrastowano hematoksyliną, odwodniono je i zamknięto przy użyciu histokitu. Pomiędzy poszczególnymi etapami procedury skrawki płukano w PBS. Preparaty oceniano w mikroskopie świetlnym.

\section{Komputerowa analiza obrazu}

Preparaty poddano procedurze skanowania (w 200-krotnym powiększeniu, rozdzielczość 0,25 $\mu \mathrm{m}$ ) skanerem ScanScope AT2 (Leica Microsystems, Niemcy). Uzyskane w ten sposób cyfrowe obrazy analizowano za pomocą programu ImageScope (wersja 11.2.0.780; Aperio Technologies, Inc., Vista, CA, USA). Do komputerowej analizy wykorzystano algorytm „nuclear V9" (Aperio Technologies, wersja 11.2.0.780).

W celu uzyskania powtarzalnych wyników reakcji immunohistochemicznych (AR, ER $\alpha, \mathrm{PCNA}$ ) i histochemicznych (TUNEL) dokonano analizy 40 losowo wybranych pół powierzchni, zarówno w analizie komórek zrębu, jak i komórek nabłonka. W reakcjach oznaczających AR oraz ER $\alpha$ siłę ekspresji oznaczano: (3+) - komórki wykazujące bardzo silną ekspresję; (2+) komórki wykazujące silną ekspresję; (1+) - komórki wykazujące słabą ekspresję, (+) - wszystkie komórki wykazujące obecność receptora. 


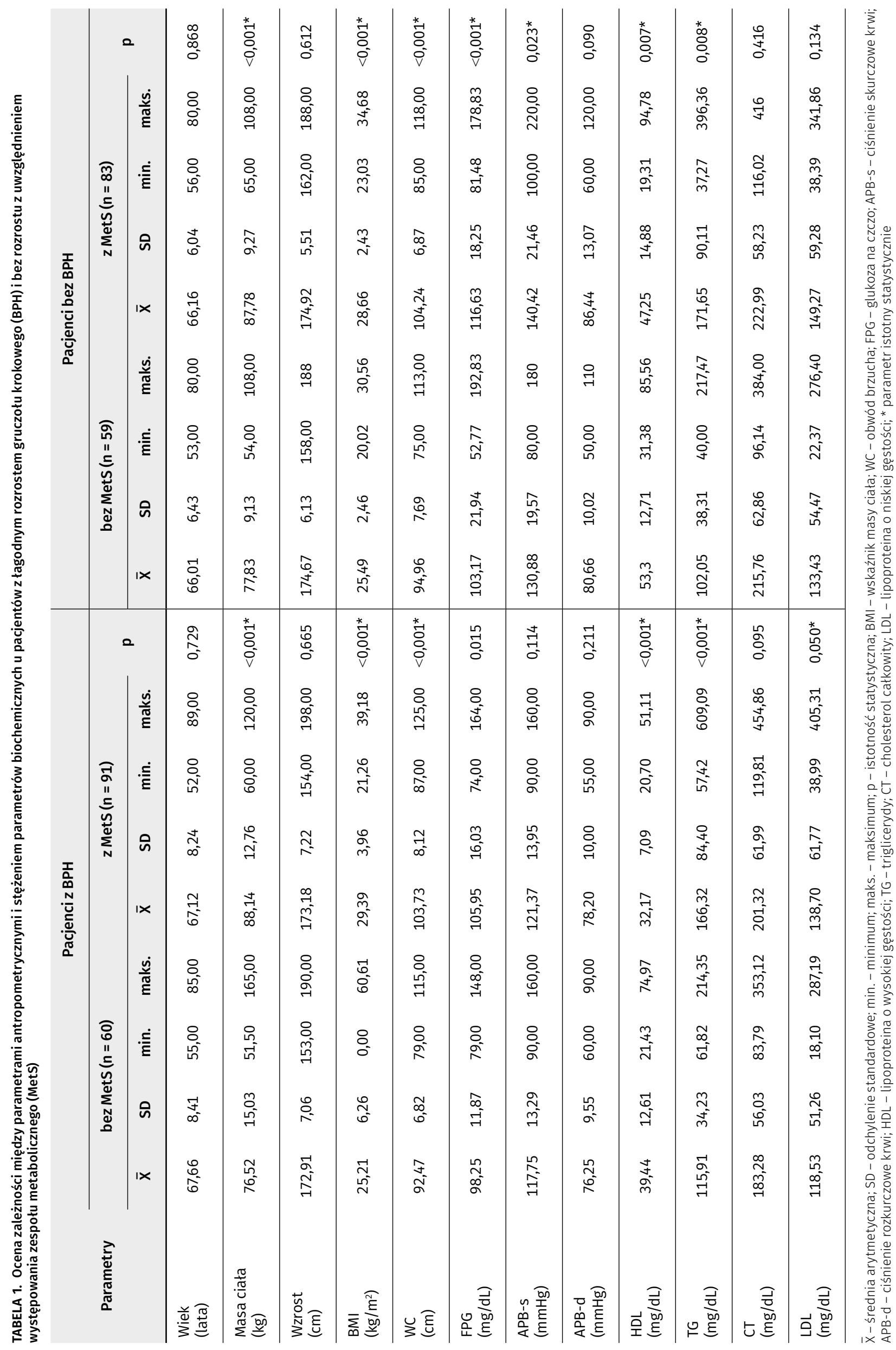




\section{Analiza statystyczna wyników}

W celu przeprowadzenia analizy statystycznej danych użyto program SPSS Statistics wersja 17.0. W grupie B i K wykonano statystykę podstawową. Normalność rozkładu badano z wykorzystaniem testu Shapiro-Wilka. W celu porównania grup wykorzystano test U Manna-Whitneya oraz test t-Studenta dla prób niezależnych. Dane nominalne badano testem $\chi^{2}$ z poprawką na ciągłość Yatesa. Korelacje między badanymi parametrami, w zależności od rodzaju danych, badano z wykorzystaniem współczynnika korelacji Pearsona. Wykonano analizę regresji logistycznej i linowej. Za wyniki istotne statystycznie przyjęto $\mathrm{p} \leq 0,05$.

\section{WYNIKI}

\section{Ocena stężeń parametrów metabolicznych i antropometrycznych u pacjentów z grupy badanej i kontrolnej}

Analiza porównawcza badanych parametrów u pacjentów z grupy badanej (z BPH) i kontrolnej (bez BPH) wykazała występowanie różnic istotnych statystycznie w stężeniu FPG $(\mathrm{p}=0,010)$, HDL $(\mathrm{p}<0,001)$ i CT $(\mathrm{p}<0,001)$ między badanymi grupami. Pacjenci z BPH mieli niższe stężenia tych parametrów niż pacjenci bez BPH. Nie wykazano różnic statystycznych między grupami w analizie wieku pacjentów oraz ich masy ciała, wzrostu, BMI, obwodu brzucha, stężenia TG i LDL.

Analizując różnice między badanymi parametrami u pacjentów z grupy B i K jako kryterium podziału przyjęto występowanie MetS (tab. 1). Wykazano występowanie istotnej statystycznie różnicy między parametrami diagnostycznymi MetS u pacjentów z MetS i bez MetS, zarówno w grupie B, jak i K. Różnice te obserwowano między: masą ciała pacjentów, wartością BMI, obwodem brzucha oraz stężeniem FPG, HDL i TG w surowicy.

Obserwowane różnice dotyczyły również stężenia ciśnienia skurczowego krwi. W grupie K obserwowano istotnie wyższą wartość ciśnienia skurczowego krwi u pacjentów z MetS $(\mathrm{p}=0,023) \mathrm{w}$ porównaniu z wartością tego ciśnienia u osób bez MetS. Różnicy tej nie obserwowano u pacjentów z grupy $\mathrm{B}$ $(\mathrm{p}=0,114)$.

Analizując zaburzenia profilu lipidowego, wykazano, że osoby z BPH i z MetS miały istotnie wyższe wartości stężenia LDL ( $p=0,050)$ niż pacjenci z BPH i bez MetS; co interesujące, zależność ta nie występowała w grupie kontrolnej $(p=0,134)$.

Należy również podkreślić, że występowanie MetS u pacjentów z BPH nie miało wpływu na nasilenie objawów towarzyszących rozrostowi stercza $(p=0,182)$.

W żadnej z grup nie obserwowano istotności statystycznej między wiekiem, wzrostem, wartością APB-d oraz stężeniem CT i LDL.

\section{Częstość występowania poszczególnych jednostek chorobowych u pacjentów z grupy badanej i kontrolnej}

Wykonano również analizę regresji logistycznej (tab. 2). Przeanalizowano potencjalne czynniki predykcyjne BPH.
TABELA 2. Regresja logistyczna. Czynniki predykcyjne tagodnego rozrostu gruczotu krokowego

\begin{tabular}{lcccc} 
& & & \multicolumn{2}{c}{$95 \% \mathrm{Cl}$} \\
\cline { 4 - 5 } Parametr & $\mathbf{p}$ & OR & $\begin{array}{c}\text { dolna } \\
\text { granica }\end{array}$ & $\begin{array}{c}\text { górna } \\
\text { granica }\end{array}$ \\
\hline $\mathrm{BMI} \geq 25 \mathrm{~kg} / \mathrm{m}^{2}$ & 0,858 & 0,954 & 0,568 & 1,601 \\
\hline WC $\geq 94 \mathrm{~cm}$ & 0,509 & 0,841 & 0,503 & 1,407 \\
\hline Nadciśnienie tętnicze & 0,274 & 1,295 & 0,815 & 2,058 \\
\hline Zaburzenia & $<0,01^{*}$ & 3,082 & 1,683 & 5,642 \\
\hline hipolipemizujące & 0,692 & 0,949 & 0,920 & 2,956 \\
\hline Cukrzyca typu 2 & $0,002^{*}$ & 2,134 & 1,333 & 3,416 \\
\hline MetS & & & &
\end{tabular}

p - istotność statystyczna; OR - iloraz szans; BMI - wskaźnik masy ciała; WC obwód brzucha; MetS - zespół metaboliczny; * parametr istotny statystycznie

Najsilniejszymi predyktorami choroby było wystąpienie u pacjentów zaburzeń frakcji lipidów (iloraz szans - OR =3,082, $\mathrm{p}<0,01)$ oraz zespołu metabolicznego $(\mathrm{OR}=2,134, \mathrm{p}=0,002)$. W analizowanym modelu otyłość brzuszna, zwiększona masa ciała oraz leczenie nadciśnienia tętniczego i cukrzycy typu 2 nie były istotnymi czynnikami predykcyjnymi BPH.

\section{Ocena stężeń parametrów hormonalnych i białek u pacjentów $z$ grupy badanej $\mathrm{i}$ kontrolnej}

W badaniu przeanalizowano różnice w stężeniach wybranych parametrów hormonalnych między pacjentami z grupy B i K. Pacjenci z grupy badanej wykazywali istotnie wyższe stężenie LH $(p<0,001)$, insuliny $(p=0,001)$ oraz wyższą wartość wskaźnika HOMA-IR $(\mathrm{p}=0,003)$ niż pacjenci z grupy kontrolnej. W grupie B obserwowano również niższe stężenia SHBG $(p<0,001)$ E2 $(p<0,001)$ oraz DHEAS $(p=0,006)$ w porównaniu z grupą kontrolną. Nie obserwowano różnicy istotnej statystycznie między stężeniami TT i TF u pacjentów z grupy B i K.

Analizując stężenia hormonów w grupie B i K z uwzględnieniem występowania MetS (tab. 3), wykazano, że zarówno w grupie badanej, jak i w grupie kontrolnej istotnie niższe było stężenie TT u pacjentów z MetS ( $\mathrm{p}=0,001 \mathrm{z}$ BPH oraz $\mathrm{p}<0,001$ bez BPH) oraz istotnie wyższe stężenie SHBG u osób bez MetS ( $p=0,002$ z BPH oraz $p=0,030$ bez BPH). Jedynie u pacjentów $\mathrm{z}$ rozrostem prostaty obserwowano istotnie wyższe stężenie E2 u osób z MetS ( $\mathrm{p}=0,050)$, podczas gdy nie obserwowano tej zależności w grupie K. U pacjentów w grupie kontrolnej wykazano istotnie niższe stężenie insuliny oraz istotnie niższą wartość wskaźnika HOMA-IR u osób bez MetS w porównaniu ze stężeniami tego parametru u pacjentów $\mathrm{z}$ MetS ( $\mathrm{p}<0,001$ dla obu grup). Zależności tej nie obserwowano w grupie $B$.

\section{Ocena morfologiczna prostaty ludzkiej}

Porównano budowę morfologiczną skrawków prostaty pobranych od mężczyzn z BPH z MetS oraz bez MetS. W obrazie histologicznym nie stwierdzono widocznych różnic budowy tego gruczołu. W obu grupach widoczne były charakterystyczne dla rozrostu prostaty palczaste wpuklenia nabłonka do światła cewek. Nie zauważono różnic w proporcji struktur 


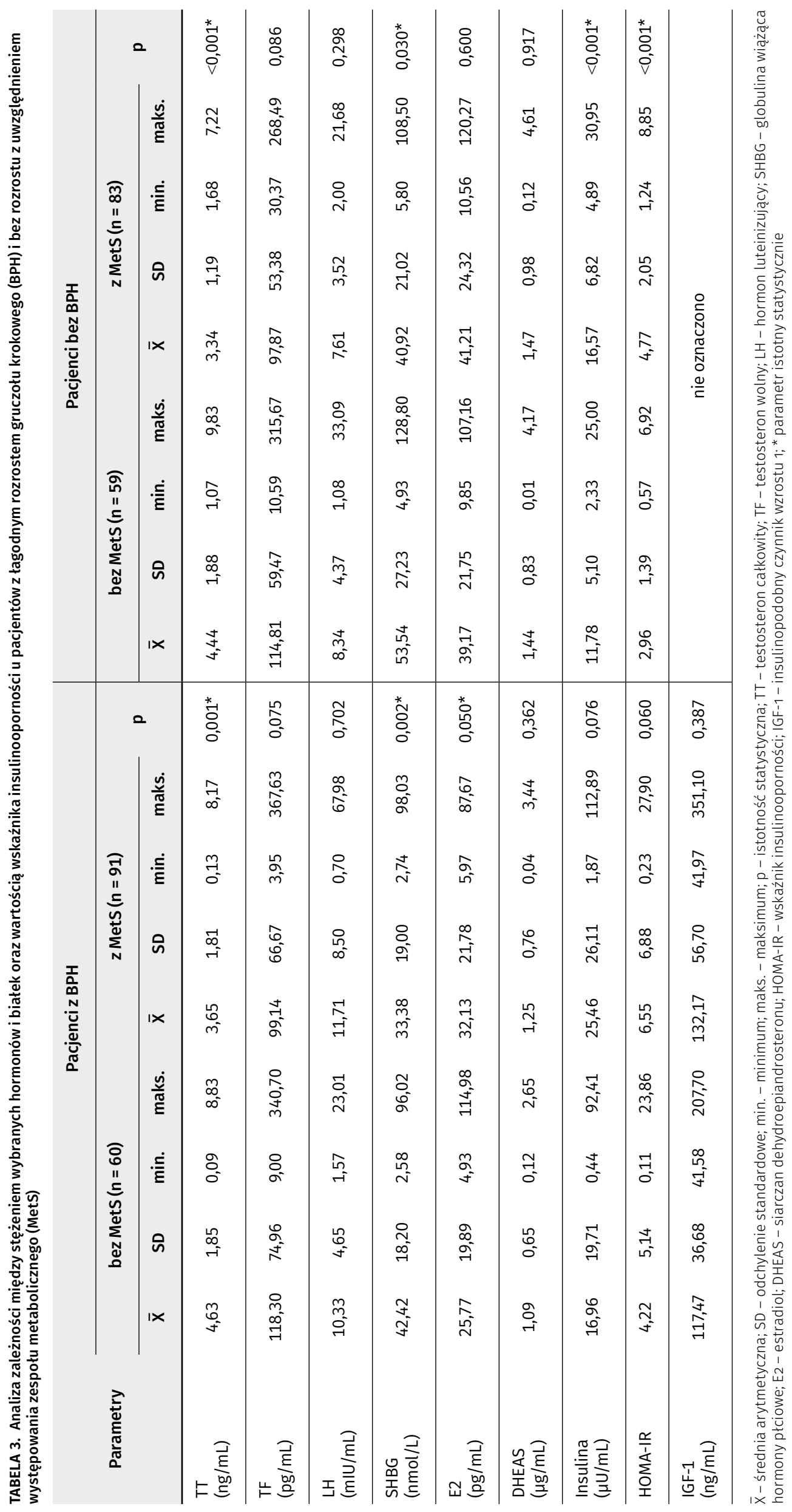


gruczołowych oraz włóknisto-mięśniowego podścieliska między grupami B1 i B2. Nie obserwowano również różnic w budowie nabłonka. Stwierdzono podobną ilość kamyczków sterczowych i naczyń krwionośnych w prostatach z MetS oraz bez MetS.

\section{Ocena reakcji immunohistochemicznych i histochemicznych}

Przeanalizowano lokalizację AR, ER $\alpha$ oraz komórek wykazujących apoptozę i proliferację w prostacie mężczyzn z BPH z MetS i bez MetS (tab. 4). Analiza porównawcza nie wykazała istnienia zależności między analizowanymi parametrami a występowaniem MetS.

\section{Analiza korelacji między oznaczanymi parametrami a lokalizacją i ekspresją komórek AR(+), ER $\alpha(+)$ oraz lokalizacją komórek PCNA(+) i TUNEL(+)}

Wykonano szczegółową analizę korelacji między oznaczanymi parametrami a lokalizacją i ekspresją AR u pacjentów z BPH z z MetS i bez MetS. Masa ciała korelowała ujemnie z liczbą komórek AR(1+) w grupie bez zdiagnozowanego MetS. Zależność tę obserwowano zarówno w komórkach zrębu $(\mathrm{P}=-0,66$, $\mathrm{p}=0,04)$, jak i w komórkach nabłonka gruczołowego $(\mathrm{P}=-0,61$, $\mathrm{p}=0,05)$. W tej samej grupie obserwowano zależność między stężeniem DHEAS a liczbą komórek AR $\left(3^{+}\right)$w zrębie stercza $(\mathrm{P}=-0,59, \mathrm{p}=0,05)$ oraz $\mathrm{w}$ komórkach nabłonka $(\mathrm{P}=-0,65$, $\mathrm{p}=0,04)$. Siarczan dehydroepiandrosteronu korelował z liczbą komórek AR(1+) w nabłonku. W grupie bez MetS również E2 korelował z liczbą komórek $\mathrm{AR}(+)$ w zrębie prostaty $(\mathrm{P}=-0,64$, $\mathrm{p}=0,03)$.

Wykazano, że liczba komórek $\mathrm{ER} \alpha(+)$ w nabłonku korelowała z wiekiem pacjentów zarówno z MetS - ER $\alpha\left(3^{+}\right)$: $\mathrm{P}=0,514, \mathrm{p}=0,03$, jak i bez MetS $-\mathrm{ER} \alpha(3+): \mathrm{P}=0,83, \mathrm{p}<0,01$; $\mathrm{ER} \alpha(2+): \mathrm{P}=0,68, \mathrm{p}=0,02$. Z wielkością obwodu brzucha korelowała liczba komórek ER $\alpha(+)$ w zrębie. Zależność tę obserwowano, analizując siłę ekspresji ER $\alpha\left(3^{+}\right)$- u osób z MetS $(\mathrm{P}=0,479, \mathrm{p}=0,04)$ oraz bez MetS $(\mathrm{P}=0,89, \mathrm{p}<0,01)$. Warto podkreślić, że wartość ta u pacjentów bez MetS w pozostałych poziomach ekspresji w komórkach zrębu osiągała istotności zbliżające się od wartości 0,05. W komórkach nabłonka gruczołowego u osób ze zdiagnozowanym zespołem metabolicznym obserwowano istotną statystycznie wartość między stężeniem FPG a liczbą komórek $\mathrm{ER} \alpha(+)-\mathrm{P}=0,56, \mathrm{p}=0,04$ oraz na $\mathrm{ER}(2+)-\mathrm{P}=0,57, \mathrm{p}=0,03$. W grupie tej podobną zależność obserwowano, analizując stężenie LDL, gdzie sumaryczna liczba komórek $\mathrm{ER} \alpha(+)$ korelowała ujemnie z tym parametrem $(P=-0,47, p=0,05)$. Zależności tej nie obserwowano w grupie pacjentów bez MetS. Z kolei w komórkach nabłonka gruczołowego u pacjentów z BPH bez MetS ze stężeniem SHBG korelowała ogólna liczba komórek $\mathrm{ER} \alpha(+)-\mathrm{P}=-0,58, \mathrm{p}=0,05$ a $\operatorname{ER} \alpha(1+)-P=-0,66, p=0,02$. W grupie tej obserwowano również zależność między liczbą komórek z ER $\alpha(1+)$ a stężeniem E2 ( $\mathrm{P}=-0,62, \mathrm{p}=0,03)$.

Przeanalizowano korelacje, dzieląc pacjentów pod względem występowania MetS. W grupie z MetS liczba komórek TUNEL(+) w nabłonku stercza korelowała ujemnie z obwodem brzucha $(\mathrm{P}=-0,53, \mathrm{p}=0,02)$. Należy podkreślić, że zależność tę na granicy istotności statycznej obserwowano również w komórkach zrębu $(P=-0,50, p=0,06)$. W tej samej grupie w nabłonku liczba komórek wykazujących apoptozę korelowała ujemnie ze stężeniem w surowicy HDL $(\mathrm{P}=-0,56, \mathrm{p}=0,02)$. Badając stężenia hormonów, wykazano, że odsetek komórek TUNEL(+) korelował dodatnio tylko ze stężeniem LH $(\mathrm{P}=0,61, \mathrm{p}=0,02)$ w surowicy osób z BPH bez MetS. Zależności tej nie obserwowano u pacjentów z MetS. Inne analizowane w badaniu hormony nie korelowały z procentową liczbą komórek w apoptozie. Wykazano, że IGF-1 korelował ujemnie u osób z MetS z liczbą komórek TUNEL(+) w nabłonku (P = -0,69, p = 0,01) oraz bez MetS w zrębie stercza $(P=-0,61, p=0,03)$.

Przeanalizowano również korelacje u pacjentów z BPH z MetS i bez MetS. Wykazano, że jedynymi parametrami korelującym z liczbą komórek PCNA(+) w zrębie stercza było stężenie insuliny $w$ surowicy osób bez MetS $(P=0,65, p=0,02)$ oraz analogiczna wartość wskaźnika HOMA-IR $(P=0,64, p=0,04)$. $\mathrm{W}$ analizie tej nie obserwowano korelacji między stężeniem SHBG a liczbą komórek PCNA(+).

TABELA 4. Porównanie lokalizacji receptora androgenowego (AR), receptora estrogenowego $\alpha$ (ERoC), jądrowego antygenu proliferacyjnego (PCNA) i reakcji identyfikującej apoptozę (TUNEL) w prostacie mężczyzn z łagodnym rozrostem bez zespołu metabolicznego (MetS) oraz z zespołem metabolicznym

\begin{tabular}{|c|c|c|c|c|c|c|c|c|c|c|}
\hline \multirow{2}{*}{\multicolumn{2}{|c|}{$\begin{array}{l}\text { Lokalizacja i ekspresja } \\
\text { odczynu }\end{array}$}} & \multicolumn{4}{|c|}{$\begin{array}{l}\text { Skrawki gruczołu krokowego } \\
\text { z tagodnym rozrostem bez MetS }\end{array}$} & \multicolumn{4}{|c|}{$\begin{array}{l}\text { Skrawki gruczołu krokowego } \\
\text { z tagodnym rozrostem z MetS }\end{array}$} & \multirow{2}{*}{$p$} \\
\hline & & $\overline{\mathrm{X}}(\%)$ & SD & $\min$. & maks. & $\bar{x}(\%)$ & SD & $\min$. & maks. & \\
\hline \multirow{4}{*}{ Komórki zrębu } & $\mathrm{AR}(+)$ & 25,57 & 12,94 & 3,05 & 48,93 & 23,25 & 11,61 & 7,34 & 39,63 & 0,670 \\
\hline & $E R \alpha(+)$ & 12,00 & 7,01 & 2,12 & 31,04 & 10,99 & 5,43 & 4,73 & 19,85 & 0,820 \\
\hline & TUNEL(+) & 20,26 & 10,08 & 6,84 & 43,45 & 16,83 & 13,86 & 3,06 & 60,71 & 0,150 \\
\hline & PCNA(+) & 34,11 & 9,92 & 16,02 & 48,18 & 28,47 & 11,42 & 13,00 & 45,34 & 0,120 \\
\hline \multirow{4}{*}{$\begin{array}{l}\text { Nabłonek } \\
\text { gruczołowy }\end{array}$} & $\operatorname{AR}(+)$ & 60,55 & 21,25 & 10,28 & 87,46 & 55,52 & 10,25 & 39,00 & 68,75 & 0,270 \\
\hline & $\mathrm{ER} \alpha(+)$ & 36,87 & 19,24 & 4,78 & 77,52 & 30,89 & 14,10 & 6,02 & 56,54 & 0,290 \\
\hline & TUNEL(+) & 39,92 & 15,23 & 12,32 & 60,52 & 41,83 & 20,14 & 5,27 & 76,89 & 0,930 \\
\hline & PCNA(+) & 61,31 & 12,31 & 30,95 & 77,53 & 55,56 & 14,97 & 31,81 & 80,92 & 0,260 \\
\hline
\end{tabular}

$\bar{X}$ - średnia arytmetyczna; SD - odchylenie standardowe; min. - minimum; maks. - maksimum; p - istotność statystyczna 


\section{DYSKUSJA}

\section{tagodny rozrost gruczołu krokowego i zespót metaboliczny a stężenie parametrów metabolicznych i parametrów antropometrycznych}

Zaburzenia metaboliczne, a w szczególności zdiagnozowanie MetS u mężczyzn, jest coraz częściej wymienianym czynnikiem predysponującym do występowania łagodnego rozrostu gruczołu krokowego. Dotychczas przeprowadzono wiele badań potwierdzających tę zależność $[15,16,17]$. Jednak nowym spojrzeniem na epidemiologię BPH jest szukanie wspólnej etiologii rozrostu prostaty i chorób sercowo-naczyniowych [18].

Wyniki badań własnych wskazują, że najsilniejszymi czynnikami warunkującymi wystąpienie BPH było zdiagnozowanie MetS oraz stwierdzenie zaburzeń frakcji lipidów u pacjentów. Mniejsze znaczenie dla zdiagnozowania BPH miały takie parametry jak stopień otyłości brzusznej oraz zwiększona masa ciała pacjenta.

Burke i wsp. [19] badali mężczyzn ze zdiagnozowanym BPH w wieku 40-71 lat, prowadząc pomiary antropometryczne ich ciała. Stwierdzili oni, że obwód brzucha nie miał wpływu na objętość stercza mierzonego metodą ultrasonografii oraz nie wpływał na przepływ moczu przez cewkę moczową. Parsons [20] na podstawie dużego badania kohortowego opracował model, dzięki któremu stwierdził, że objętość prostaty wzrasta aż o 0,41 mL wraz ze wzrostem BMI o $1 \mathrm{~kg} / \mathrm{m}^{2}$. Autor ten zauważył również, że pacjenci z BMI $\geq 35 \mathrm{~kg} / \mathrm{m}^{2}$, kwalifikowanym wg standardów Światowej Organizacji Zdrowia jako otyłość II stopnia, mieli 3,5-krotnie wyższe ryzyko wystąpienia BPH w porównaniu z osobami z prawidłową masą ciała $\left(\mathrm{BMI}<25 \mathrm{~kg} / \mathrm{m}^{2}\right.$ ). Inna grupa badaczy [21] przeprowadziła metaanalizę obejmującą 5403 pacjentów z rozrostem prostaty pochodzących z różnych krajów. Zostali oni podzieleni na dwie grupy - z MetS i bez MetS. Według tych autorów mężczyźni z MetS mieli znacznie większą objętość prostaty w porównaniu z tymi bez MetS. Wśród parametrów diagnozowanych w etiologii zespołu metabolicznego tylko obwód brzucha i stężenie HDL były istotne w ustaleniu ryzyka wystąpienia BPH.

Insulinooporność jest jedną z przyczyn hiperinsulinemii, uważanej za kluczowy czynnik w interakcji między MetS a BPH [22]. Stężenie insuliny, insulinopodobnego czynnika wzrostu, występująca otyłość [23] i cukrzyca są uważane za niezależne czynniki ryzyka rozwoju BPH [24]. Badania podobne do własnych przeprowadzili Nandeesha i wsp. [23] na grupie 88 mężczyzn. Wskaźnik HOMA-IR był znacząco wyższy u mężczyzn z BPH. Ponadto wykazali oni, że stężenie insuliny na czczo było istotnie wyższe u mężczyzn z BPH (średnia 237,4 pmol/L) w porównaniu ze stężeniem tego parametru u mężczyzn w grupie kontrolnej (134,7 pmol/L, p < 0,001). Stwierdzili również, że insulinooporność może być niezależnym czynnikiem ryzyka rozwoju BPH. Jednak analiza wyników badań własnych nie wykazała występowania istotnych różnic między wskaźnikiem HOMA-IR w porównywanych grupach (B1 i B2).

Związek między zaburzeniami gospodarki lipidowej a patogenezą BPH został dobrze udokumentowany [25, 26, 27]. Nadal jednak brak jest jednoznacznych danych na temat tego, które z oznaczanych frakcji lipidów są związane z patogenezą choroby. Wyniki badań własnych sugerują, że występowanie MetS i zaburzeń gospodarki lipidowej jest czynnikiem zwiększającym ryzyko BPH. Zauważono zależność między stężeniem LDL a diagnozowaniem zaburzeń metabolicznych w przebiegu BPH i samym wystąpieniem rozrostu. Zależności tej nie obserwowano dla innych frakcji lipidowych analizowanych w badaniach własnych. Diagnozowanie MetS u zdrowych pacjentów nie mało związku ze stężeniem LDL, jednak u osób z BPH obserwowano zależność między tymi parametrami. Fizjologiczny mechanizm tej zależności nie został poznany. Głównym narzędziem wykorzystywanym przez badaczy są doświadczenia przeprowadzane na modelach zwierzęcych, które koncentrują się na wpływie diety wysokotłuszczowej na patologiczny rozrost prostaty $[25,26]$.

\section{Łagodny rozrost gruczołu krokowego i zespół metaboliczny a stężenie parametrów hormonalnych i białek}

Wyniki badań wielu autorów dostarczają sprzecznych danych dotyczących zależności między wpływem zaburzeń metabolicznych i stężeniem hormonów zaangażowanych w etiopatogenezę rozrostu gruczołu krokowego.

W procesie starzenia spadek stężenia testosteronu u mężczyzn jest zaburzeniem fizjologicznym [28]. Jednak spadek stężenia testosteronu występujący w przebiegu rozrostu prostaty wraz z współistniejącymi zaburzeniami metabolicznymi jest sprawą dyskusyjną. Od wielu lat wiadomo, że testosteron oraz dihydrotestosteron biorą udział we wzroście i proliferacji komórek stercza [5, 29].

W badaniach własnych wykazano, że stężenie testosteronu nie było bezpośrednio związane z występowaniem BPH u pacjentów. Badania porównujące zależności między stężeniem testosteronu całkowitego a masą ciała osób ze schorzeniami ze strony LUTS przeprowadzili Antunes i wsp. [30]. Wykazali oni, że w grupie 725 otyłych mężczyzn (średnia wieku 65 lat, BMI $\geq 25$ ) wiek i stężenie TT były związane z objawami ze strony dolnych dróg moczowych. Autorzy nie obserwowali zależności między stężeniem TF i SGBG a badanymi parametrami. Podobne badania u mężczyzn z BPH przeprowadzili Kaplan i wsp. [29], którzy zaobserwowali występowanie zależności między niskim stężeniem testosteronu a występowaniem otyłości.

Rola estrogenów w regulacji układu płciowego męskiego została już dość dobrze poznana [31, 32]. U mężczyzn estrogeny pochodzą głównie z procesu obwodowej aromatyzacji testosteronu [32]. Z wiekiem stężenie E2 w surowicy pozostaje stabilne lub zwiększa się, w wyniku czego zwiększa się stosunek E2 do TT [31]. Badania przeprowadzone na modelu zwierzęcym [33] potwierdziły, że zmiany stosunku stężeń E2 do TT przyczyniły się do stopniowego zwiększenia objętości stercza szczurów i do występowania zaburzeń w oddawaniu moczu. Jednak badania te nie potwierdziły hipotezy, że zmiany proporcji stężenia obu hormonów związane były z objawami ze strony LUTS oraz niedrożnością cewki moczowej. 
Badanie stężeń hormonów płciowych na dużej grupie starzejących się mężczyzn, u których zdiagnozowano BPH, przeprowadzili Tan i wsp. [34]. Potwierdzili oni, że pacjenci z rozrostem prostaty mieli wyższe stężenia E2 niż bez rozrostu tego gruczołu. Podobną zależność stwierdzili Partin i wsp. [5], którzy obserwowali pozytywną korelację między stężeniem estradiolu i testosteronu wolnego a objętością prostaty.

\section{Wpływ występowania zespołu metabolicznego i zaburzeń stężeń hormonów u pacjentów z łagodnym rozrostem gruczołu krokowego na lokalizację i ekspresję receptora androgenowego i estrogenowego $\alpha$ w komórkach prostaty}

Przeprowadzone badania wykazały, że zaburzenia metaboliczne u mężczyzn z BPH nie wpływają bezpośrednio na lokalizację i ekspresję AR, zarówno w komórkach zrębu, jak i w komórkach nabłonka gruczołowego. Wykazano natomiast, że u pacjentów z BPH występuje zależność między liczbą tych receptorów a stężeniem wolnego testosteronu w surowicy. Wykazano również, że zdiagnozowanie MetS u osób z BPH wpływa na zależność między liczbą komórek AR(+) a stężeniem E2 i DHEAS.

Biolchi i wsp. [35] przeprowadzili analizę genotypu i stężeń testosteronu w grupie 126 pacjentów w wieku 40-60 lat, u których objętość stercza w obrazie USG była większa niż 30 mL. Autorzy wykazali, że obecność dużej liczby powtórzeń GGC w genie kodującym AR oraz niższe stężenie testosteronu w surowicy predysponują do większego ryzyka wystąpienia rozrostu stercza.

Najnowsze badania Zhanga i wsp. [36] wykazały, że występowanie stanu zapalnego w gruczole krokowym może być związane z etiologią łagodnego rozrostu. Autorzy ci zauważyli, że spadek ekspresji genów związanych z powstawaniem receptora androgenowego $w$ komórkach prostaty koreluje z wyższym stopniem regionalnego zapalenia gruczołu krokowego. Jednakże, związek przyczynowo-skutkowy między tymi dwoma procesami pozostaje nadal niejasny. Vignozzi i wsp. [37] zaobserwowali korzystny wpływ podawania testosteronu pacjentom z BPH na poprawę ich parametrów metabolicznych. W związku z ich badaniami można przypuszczać, że zwiększona liczba receptorów androgenowych może mieć bezpośrednie działanie ochronne na komórki ludzkiej prostaty, ze względu na zdolność reagowania komórek stercza na zmianę stężeń parametrów metabolicznych. Badania własne wykazały, że zdiagnozowanie MetS u pacjentów z BPH nie wpływało na lokalizację i ekspresję ER $\alpha$ w gruczole krokowym. Jednak zdiagnozowanie MetS u osób z BPH wpływało na równowagę między liczbą komórek $\mathrm{ER} \alpha(+)$ w komórkach nabłonka gruczołowego stercza a stężeniem E2 i SHBG w surowicy. Wykazano również, że wraz z wiekiem u pacjentów z BPH wzrastała liczba komórek $\operatorname{ER} \alpha(+)$ w nabłonku, z kolei nie obserwowano tej zależności w zrębie stercza. W materiale własnym oznaczono liczbę ER $\alpha$ w komórkach gruczołu krokowego, natomiast badanie ER $\beta$ w komórkach prostaty jest zaplanowane jako kontynuacja tej pracy.
W badaniu na modelu zwierzęcym Ricke i wsp. [38] wykazali, że u samców myszy, którym podawano estrogeny, liczba komórek $\mathrm{ER} \alpha(+)$ w nabłonku gruczołu krokowego wzrastała, podczas gdy liczba komórek $E R \alpha(+)$ w zrębie zmniejszała się. Wykazano również, że estrogeny mogą brać udział w proliferacji komórek nabłonka gruczołu krokowego.

Ponadto aromataza cytochromu P450, główny enzym zaangażowany w biosyntezę hormonów steroidowych, biorący udział w aromatyzacji androgenów do estrogenów [39], jest aktywna nie tylko w tkance tłuszczowej, lecz również w układzie moczowo-płciowym [40].

\section{Wpływ zespołu metabolicznego i zaburzeń stężeń hormonów na występowanie komórek apoptotycznych i komórek proliferujących w prostacie mężczyzn z tagodnym rozrostem}

Proces apoptozy odgrywa ważną rolę zarówno w regulacji wzrostu komórek, jak i w utrzymaniu homeostazy tkanki. Obejmuje on wiele zmian na poziome komórkowym, które w efekcie doprowadzają do śmierci komórek o upośledzonych funkcjach [41]. Wykazano, że zwiększona ekspresja genów regulujących apoptozę ma wpływ na patologiczny rozrost prostaty człowieka, a także istotna jest w etiologii nowotworów prostaty [42].

W przeprowadzonych badaniach nie wykazano zależności między stężeniem insuliny a ogólną liczbą komórek TUNEL(+) w nabłonku i zrębie prostaty. Jednak w piśmiennictwie opisano zależność między insulinoopornością a silniejszą ekspresją receptorów dla IGF-1, który jest silnym mitogenem i wykazuje działanie antyapoptotyczne. Związek ten wydaje się istotny w analizie czynników zwiększających ryzyko wystąpienia BPH u pacjentów z MetS [43]. Warte podkreślenia jest to, że w badaniach własnych u osób z BPH i MetS liczba komórek TUNEL(+) korelowała ujemnie z obwodem brzucha. Zależności tej nie obserwowano u mężczyzn w grupie kontrolnej. Może to potwierdzać teorię uwzględniającą wielkość obwodu brzucha jako czynnika wpływającego na występowanie apoptozy w komórkach prostaty u pacjentów z BPH. Otyłość brzuszna i hiperinsulinemia analizowane były również jako czynniki związane ze wzrostem stężenia krążącego bioaktywnego IGF-1.

W badaniach własnych wystąpienie MetS u osób z BPH nie wpływało na lokalizację i ekspresję komórek PCNA(+) w sterczu. Jednak u pacjentów z BPH, u których zdiagnozowano MetS, stwierdzono dodatnią zależność między stężeniem insuliny i wartością wskaźnika HOMA-IR a liczbą komórek PCNA(+) w zrębie stercza.

Badania dotyczące komórek PCNA(+) opierają się na sprawdzaniu zależności między komórkami występującymi w prostacie z BPH a komórkami nowotworowymi prostaty. Pacjenci z BPH najczęściej stanowią grupę kontrolną. Badania takie przeprowadzili Zhong i wsp. [44], którzy wykazali, że markery Ki-67 i PCNA wykazują silniejszą ekspresję w nowotworach i w BPH w porównaniu ze zdrową tkanką ludzkiego gruczołu krokowego. Natomiast stosunek ekspresji obu analizowanych markerów w tkance nowotworu stercza był podwyższony 
w porównaniu z tym stosunkiem występującym w prostacie mężczyzn z BPH.

\section{WNIOSKI}

1. Występowanie rozrostu prostaty związane było ze zmianami stężeń hormonów: LH, SHBG, E2 i insuliny, jednak nie było związane bezpośrednio ze zmianami stężeń TT i TF. Wykazano jednak, że zaburzenia metaboliczne diagnozowane u pacjentów z BPH powodowały obniżenie stężeń testosteronu całkowitego i SHBG w surowicy krwi. Stwierdzono również, że zdiagnozowanie MetS u osób z BPH było związane z większym stężeniem u nich E2 i insuliny, podczas gdy nie obserwowano tej zależności w grupie bez BPH. Występowanie MetS u pacjentów z BPH nie wpływało na stężania: TF, LH, E2 i DHEAS.

2. Zmiany stężenia parametrów metabolicznych, hormonalnych i białek nie wpływały na stopień nasilenia objawów klinicznych towarzyszących łagodnemu rozrostowi gruczołu krokowego oraz na jego budowę morfologiczną.

3. Zespół metaboliczny zdiagnozowany u pacjentów z BPH nie miał wpływu na lokalizację i ekspresję AR i ER $\alpha$ oraz na liczbę komórek w apoptozie i liczbę komórek proliferujących w prostacie. Istotnym czynnikiem powodującym zmianę liczby komórek $\mathrm{ER} \alpha(+)$ oraz powodującym zmniejszenie liczby komórek TUNEL(+) u osób z BPH było występowanie otyłości centralnej.

4. Wykazano, że wraz z wiekiem u pacjentów z BPH, niezależnie od występowania zaburzeń metabolicznych, wzrastała liczba komórek $E R \alpha(+)$ w nabłonku prostaty. U osób z BPH bez zdiagnozowanego MetS wzrost stężenia insuliny oraz wartość wskaźnika HOMA-IR może korelować ze wzrostem liczby komórek proliferujących w prostacie.

\section{PIŚMIENNICTWO}

1. Guess HA. Benign prostatic hyperplasia: antecedents and natural history. Epidemiol Rev 1992;14:131-53.

2. Soulitzis N, Karyotis I, Delakas D, Spandidos DA. Expression analysis of peptide growth factors VEGF, FGF2, TGFB1, EGF and IGF1 in prostate cancer and benign prostatic hyperplasia. Int J Oncol 2006;29(2):305-14.

3. Smith P, Rhodes NP, Ke Y, Foster CS. Upregulation of estrogen and androgen receptors modulate expression of FGF-2 and FGF-7 in human, cultured, prostatic stromal cells exposed to high concentrations of estradiol. Prostate Cancer Prostatic Dis 2002;5(2):105-10. doi: 10.1038/sj.pcan.4500571.

4. Słuczanowska-Głabowska S, Laszczyńska M, Głabowski W, Wylot M. Morphology of the epithelial cells and expression of androgen receptor in rat prostate dorsal lobe in experimental hyperprolactinemia. Folia Histochem Cytobiol 2006;44(1):25-30.

5. Partin AW, Oesterling JE, Epstein JI, Horton R, Walsh PC. Influence of age and endocrine factors on the volume of benign prostatic hyperplasia. J Urol 1991;145(2):405-9.

6. Montie JE, Pienta KJ. Review of the role of androgenic hormones in the epidemiology of benign prostatic hyperplasia and prostate cancer. Urology 1994;43(6):892-9.

7. Griffiths K. Molecular control of prostate growth. In: Kirby R, McConnell JD, Fitzpatrick JM, editors. Textbook of benign prostatic hyperplasia. Oxford: Isis Medical Media; 1996. p. 23-6.

8. Zhang MD, Zhao YN, AnLW. B-cell lymphoma/leukemia-2 and benign prostatic hyperplasia. Zhonghua Nan Ke Xue 2009;15(5):452-4.
9. Roehrborn CG. Pathology of benign prostatic hyperplasia. Int J Impot Res 2008;20:11-8. doi: 10.1038/ijir.2008.55.

10. He Q, Wang H, Yue Z, Yang L, Tian J, Liu G, et al. Waist circumference and risk of lower urinary tract symptoms: a meta-analysis. Aging Male 2014;17(4):223-9. doi: 10.3109/13685538.2014.967671.

11. Gacci M, Vignozzi L, Sebastianelli A, Salvi M, Giannessi C, De Nunzio C, et al. Metabolic syndrome and lower urinary tract symptoms: the role of inflammation. Prostate Cancer Prostatic Dis 2013;16(1):101-6. doi: 10.1038/pcan.2012.44

12. Alberti KG, Zimmet $P$, Shaw J. The metabolic syndrome - a new worldwide definition. Lancet 2005;366:1059-62. doi: 10.1016/S0140-6736(05)67402-8.

13. WHO Expert Consultation. Appropriate body-mass index for Asian populations and its implications for policy and intervention strategies. Lancet 2004;363:157-63. doi: 10.1016/S0140-6736(03)15268-3.

14. Wesołowski P, Wańkowicz Z. Insulin resistance diagnostic methods and clinical outcomes. Nefrol Dial Pol 2011;15:243-6.

15. Zhang X, Zeng X, Liu Y, Dong L, Zhao X, Qu X. Impact of metabolic syndrome on benign prostatic hyperplasia in elderly Chinese men. Urol Int 2014;93(2):214-9. doi: 10.1159/000357760.

16. Pashootan P, Ploussard G, Cocaul A, de Gouvello A, Desgrandchamps F. Association between metabolic syndrome and severity of lower urinary tract symptoms: observational study in a 4,666 European men cohort. BJU Int 2015;116(1):124-30. doi: 10.1111/bju.12931.

17. Fleshner NE, Bhindi B. Metabolic syndrome and diabetes for the urologist. Can Urol Assoc J 2014;8:159-61. doi: 10.5489/cuaj.2314.

18. Ejike CE, Ezebuiro CO. Cardiometabolic risk factors' Prevalence in a population of geriatrics with elevated serum prostate specific antigen levels. Continental J Med Res 2011;5(2):6-13.

19. Burke JP, Rhodes T, Jacobson DJ, McGree ME, Roberts RO, Girman CJ, et al. Association of anthropometric measures with the presence and progression of benign prostatic hyperplasia. Am J Epidemiol 2006;164(1):41-6. doi: 10.1093/aje/kwj151.

20. Parsons JK. Modifiable risk factors for benign prostatic hyperplasia and lower urinary tract symptoms: New approaches to old problems. J Urol 2007;178(2):395-401. doi: 10.1016/j.juro.2007.03.103.

21. Kim WT, Yun SJ, Choi YD, Kim GY, Moon SK, Choi YJ, et al. Prostate size correlates with fasting blood glucose in non-diabetic benign prostatic hyperplasia patients with normal testosterone levels. J Korean Med Sci 2011;26(9):1214-8. doi: 10.3346/jkms.2011.26.9.1214.

22. Hammarsten J, Damber JE, Karlsson M, Knutson T, Ljunggren O, Ohlsson C, et al. Insulin and free oestradiol are independent risk factors for benign prostatic hyperplasia. Prostate Cancer Prostatic Dis 2009;12(2):160-5. doi: 10.1038/pcan.2008.50.

23. Nandeesha H, Koner BC, Dorairajan LN, Sen SK. Hyperinsulinemia and dyslipidemia in non-diabetic benign prostatic hyperplasia. Clin Chim Acta 2006;370(1-2):89-93. doi: 10.1016/j.cca.2006.01.019.

24. Vikram A, Jena G, Ramarao P. Insulin-resistance and benign prostatic hyperplasia: the connection. Eur J Pharmacol 2010;641(2-3):75-81. doi: 10.1016/j.ejphar.2010.05.042.

25. Ploumidou K, Kyroudi-Voulgari A, Perea D, Anastasiou I, Mitropoulos D. Effect of a hypercholesterolemic diet on serum lipid profile, plasma sex steroid levels, and prostate structure in rats. Urology 2010;76(6):1517. doi: 10.1016/j.urology.2010.07.515.

26. Rahman NU, Phonsombat $S$, Bochinski D, Carrion RE, Nunes L, Lue TF. An animal model to study lower urinary tract symptoms and erectile dysfunction: the hyperlipidaemic rat. BJU Int 2007;100(3):658-63. doi: 10.1111/j.1464-410X.2007.07069.x.

27. Freeman MR, Solomon KR. Cholesterol and benign prostate disease. Differentiation 2011;82(4-5):244-52. doi: 10.1016/j.diff.2011.04.005.

28. Rabijewski M. Patogeneza i objawy zespołu niedoboru testosteronu. Prz Urol 2008;9:20-6.

29. Kaplan SA, Lee JY, O'Neill EA, Meehan AG, Kusek JW. Prevalence of low testosterone and its relationship to body mass index in older men with lower urinary tract symptoms associated with benign prostatic hyperplasia. Aging Male 2013;16(4):169-72. doi: 10.3109/13685538.2013.844786.

30. Antunes AA, Araújo LH, Nakano E, Muracca E, Srougi M. Obesity may influence the relationship between sex hormones and lower urinary tract symptoms. Int Braz J Urol 2014;40(2):240-6. doi: 10.1590/S16775538.IBJU.2014.02.15.

31. Belanger A, Candas B, Dupont A, Cusan L, Diamond P, Gomez J, et al. Changes in serum concentrations of conjugated and unconjugated steroids 
in 40- to 80-yearold men. J Clin Endocrinol Metab 1994;79(4):1086-90. doi: $10.1210 /$ jcem.79.4.7962278.

32. Oszukowska E, Słowikowska-Hilczer J, Lipiński M, Kula K. Changes in estradiol and testosterone secretions in man with leydigioma and after removal of the tumour. Urol Pol 2003;56:2.

33. Bernoulli J, Yatkin E, Konkol Y, Talvitie EM, Santti R, Streng T. Prostatic inflammation and obstructive voiding in the adult Noble rat: impact of the testosterone to estradiol ratio in serum. Prostate 2008;68(12):1296 306. doi: 10.1002/pros.20791.

34. Tan MO, Karabiyik I, Uygur MC, Diker Y, Erol D. Serum concentrations of sex hormones in men with severe lower urinary tract symptoms and benign prostatic hyperplasia. Int Urol Nephrol 2003;35(3):357-63.

35. Biolchi V, Silva Neto B, Pianta DB, Koff WJ, Berger M, Brum IS. Androgen receptor GGC polymorphism and testosterone levels associated with high risk of prostate cancer and benign prostatic hyperplasia. Mol Biol Rep 2013;40(3):2749-56. doi: 10.1007/s11033-012-2293-5.

36. Zhang B, Kwon OJ, Henry G, Malewska A, Wei X, Zhang L, et al. Non-cellautonomous regulation of prostate epithelial homeostasis by androgen receptor. Mol Cell 2016;63(6):976-89. doi: 10.1016/j.molcel.2016.07.025.

37. Vignozzi L, Gacci M, Cellai I, Santi R, Corona G, Morelli A, et al. Fat boosts, while androgen receptor activation counteracts, BPH-associated prostate inflammation. Prostate 2013;73:789-800. doi: 10.1002/pros.22623.

38. Ricke WA, McPherson SJ, Bianco JJ, Cunha GR, Wang Y, Risbridger GP. Prostatic hormonal carcinogenesis is mediated by in situ estrogen production and estrogen receptor alpha signaling. FASEB J 2008;22(5):1512-20. doi: 10.1096/fj.07-9526com.

39. Nicholson TM, Ricke WA. Androgens and estrogens in benign prostatic hyperplasia: past, present and future. Differentiation 2011;82:184-99. doi: 10.1016/j.diff.2011.04.006.

40. Chavalmane K, Comeglio P, Morelli A, Filippi S, Fibbi B, Vignozzi L, et al. Sex steroid receptors in male human bladder: expression and biological function. J Sex Med 2010;7:2698-713.

41. Sebastiano C, Vincenzo F, Tommaso C, Giuseppe S, Marco R, Ivana C, et al. Dietary patterns and prostatic diseases. Front Biosci (Elite Ed) 2012;4:195-204.

42. Rodriguez-Berriguete G, Fraile B, de Bethencourt FR, Prieto-Folgado A, Bartolome N, Nunez C, et al. Role of IAPs in prostate cancer progression: immunohistochemical study in normal and pathological (benign hyperplastic, prostatic intraepithelial neoplasia and cancer) human prostate. BMC Cancer 2010;10:18. doi: 10.1186/1471-2407-10-18.

43. Ngo TH, Barnard RJ, Leung PS, Cohen P, Aronson WJ. Insulin-like growth factor I (IGF-I) and IGF binding protein-1 modulate prostate cancer cell growth and apoptosis: possible mediators for the effects of diet and exercise on cancer cell survival. Endocrinology 2003;144(6):2319-24. doi: 10.1210/en.2003-221028.

44. Zhong W, Peng J, He H, Wu D, Han Z, Bi X, et al. Ki-67 and PCNA expression in prostate cancer and benign prostatic hyperplasia. Clin Invest Med 2008;31(1):8-15. 